\title{
Scandals stem from the low priority of peer review
}

\section{Good refereeing should be recognized and rewarded, with help from the journals.}

Sir-As part of the continuing debate over the future of scientific publications, I wish to make two comments and to advance a suggestion.

First, what is the difference between a published paper and a paper that has been uploaded by its authors onto some electronic archive? The difference is that one has been refereed, the other has not. So, refereeing is clearly at the core of the scientific publishing business.

Second, what are the calls on a scientist's time? These, in order, are: (1) to bring more money into the laboratory; (2) to write and publish more papers and conference communications; (3) to write reports for the funding agencies; (4) to get some science done; (5) to teach and/or carry out administration; (6) to sit on committees that distribute the money; and (7) to referee papers.

It is a real temptation today for a referee to clear a paper off his or her desk by writing a casual and ill-considered report. If refereeing is to be done better than of late (and recent scandals involving famous laboratories are revealing), it must move up the list of priorities.

The best solution would be to include refereeing as a factor in assessment for recruitment and promotion, and perhaps even for the allocation of funds. This requires a measure to be devised, which should probably be based on information provided by the quality scientific journals.

If scientific publishers wish to avoid embarrassing fiascos and to ensure that the publication process remains reliable, they would do well to address this issue. Otherwise, the core of their business is at risk.

Jean-Patrick Connerade

Euroscience, 8 rue des Ecrivains, F-76000 Strasbourg, France

\section{Eastern Europe: progress stifled by the old guard}

Sir - Your Editorial "Eastern promise" (Nature 426, 369; 2003) argued that integrating several eastern European countries into the European Union (EU) might boost European science owing to their untapped human potential. You suggest that integration will be a shortterm challenge for the EU, but will ultimately strengthen it.

As a scientist from Poland - one of the EU members-to-be - who has worked both in Western Europe and now in the United States, I must strongly disagree with your conclusion.

It is true that there is great human potential in eastern Europe. However, you seriously underestimate the power of the scientific establishment in those countries — ranks of professors promoted during communist times - to hinder progress. Educated, hard-working scientists flee whenever possible, either by abandoning science altogether or by emigrating, usually to the United States, because the job market is tough in the EU. Few are brave enough to fight to work in their homeland.

The only way to unleash any hidden human potential is by drastic reform of science and higher education in countries such as Poland. Sadly, there are no signs of change on the horizon. Western scientists rarely understand how science works in the east. In Poland it is hierarchical, immobile, hermetic and gerontocratic. Recognition comes from having a professorship, and the postdoctorate qualification called habilitation, not from publications in internationally recognized journals with high impact factors. A scientific career after $\mathrm{PhD}$ and habilitation depends on personal and political connections. Future professors require a certain number of publications, so they publish worthless papers in countless Polish 'scientific' journals.

Once they have been promoted, the professors are no longer required to do any real research. Their titles are bestowed for life, and a head of department keeps that position until retirement. Professors usually work in the university where they completed their undergraduate, graduate and $\mathrm{PhD}$ studies, where everybody knows everybody else. Outsiders are rare and nepotism is common. Entire generations gain professorships because they are relatives or favourites of previous professors. Most research money is distributed by arbitrary administrative decisions, not as peer-reviewed grants.

Polish universities are ruled by democratic elections, but the scientific establishment is not interested in change. Some professors are creating the illusion of reform under the auspices of the president of Poland - but it is difficult to expect them to undermine their own existence.

Integrating eastern European science into the EU will do more harm than good unless the EU enforces real reforms in those countries. To thrive, science in eastern Europe must become part of the international scientific community: the habilitations and titular professorships must be abolished, scientific merit must be the only measure of an individual's qualifications, and money for research must be distributed by a competition among peer-reviewed applications.

I fear that Europe lacks the political will to modernize science. Even within the EU, anachronisms in several countries make their science less competitive than that of the United States.

One day I would like to work again in Europe, especially in Poland. But as it is now, the heart of science beats on the other side of the Atlantic.

Cezary Wójcik

University of Texas Southwestern Medical Center, Department of Physiology, 5323 Harry Hines Boulevard, Dallas, Texas 75390-9040, USA

\section{Eastern Europe needs a competitive atmosphere}

Sir - Eastern European science is underfunded and lags behind the major players. However, as your Editorial suggests (Nature 426, 369; 2003), the great human potential in terms of qualified scientists and excellent students provides a solid basis for growth.

During my scientific career I have had the chance to work both in the European Union (EU) and in Slovakia, which is due to join the EU this year. In my view, the problem is not only financial, as there are well-funded laboratories in eastern Europe with state-of-the-art equipment. What is missing is the competitive atmosphere found in top-class research centres. Foreign scientists are very rare in eastern European countries, which make no significant effort to attract experienced scientists from abroad - unlike emerging economies in Asia (see, for example, Nature 420, 257; 2002).

One solution would be to establish new international research centres in eastern Europe. Apart from the International Institute of Molecular and Cell Biology in Warsaw (Nature 421, 471-472; 2003), genuine international research centres have been absent in these countries. Establishing such centres will help prevent the brain drain and will be an effective way to harness talent in eastern Europe. Juraj Gregan IMP (Research Institute of Molecular Pathology), Dr. Bohr-Gasse 7, A-1030 Vienna, Austria 